\title{
Experimental Assessment of Performance of XCC Pile in Sand
}

\author{
B. M. Kalbande, A. I. Dhatrak, S. W. Thakare
}

\begin{abstract}
XCC (X-Section Cast in place Concrete) pile is new type of pile developed on the basis of cast-in-place pile from the conventional circular pile and capable of resisting displacement. In this study, an attempt is made to investigate the performance of XCC Pile under different loading conditions viz., vertical loading, lateral loading and uplift loading. Experimental investigation is carried out on small scale model piles embedded in sand, by changing type of loading and distance between arc to diameter ratio of the pile. The relative density of soil, type of soil and spacing between the piles are kept constant during investigations. Ultimate capacities of piles are compared with those of conventional circular pile with same diameter and length. The results show that XCC pile with arc distance to diameter ratio equal to 0.3 provides higher vertical and lateral capacity to the extent of $45 \%$ and $39 \%$ respectively compared to that of conventional pile. XCC Pile with arc distance to diameter ratio equal to 0.4 provides higher uplift load capacity to the extent $29 \%$ compared to conventional circular pile.
\end{abstract}

Keywords: XCC Pile, Ultimate load capacity, Lateral load capacity, Uplift load capacity

\section{INTRODUCTION}

When shallow foundations cannot provide sufficient bearing capacity or where the settlement is a major concern, pile foundation plays an important role in supporting structural loads. The traditional straight pile uses only the shaft skin resistance and the enlarged bottom pile uses only the end resistance provided by the bottom soil strata. In case of ordinary section pile, a straight hole of required diameter is first bored to the designed depth. Then the digging instrument is inserted into the bore hole to form a mold with digging instrument at the proper position of the soil according to design of pile for the construction. In this case, the soil around the mold becomes relaxed and stress release phenomenon occurred in the process of digging, so that the strength of the soil decreases. It reduces the frictional resistance between pile and the soil, and ultimately affects the total load carrying capacity of pile. In order to make up for the defects of this variable-section pile, the engineers invented the new type of pile called XCC pile. XCC pile is new type of pile introduced by Geotechnical Institute of Hohai University had been patented in China. XCC pile have good axial, lateral and uplift load capacity with reduction of settlement. Arc distance (b) to diameter (D) ratio of XCC pile affects its performance. Use of XCC pile is economical than that of conventional circular pile.

Revised Manuscript Received on February 05, 2020.

* Correspondence Author

Dr. A. I. Dhatrak, Associate Professor, Department of Civil Engineering, Government College of Engineering, Amravati, India

B. M. Kalbande, Department of Civil Engineering, Rashtrasant Tukdoji Maharaj Nagpur University, India.

S. W. Thakare, Associate Professor, Department of Civil Engineering, Government college of Engineering, Jalgaon, India.

(C) The Authors. Published by Blue Eyes Intelligence Engineering and Sciences Publication (BEIESP). This is an open access article under the CC BY-NC-ND license (http://creativecommons.org/licenses/by-nc-nd/4.0/)
A large-scale test was conducted on instrumented XCC piled embankment to investigate the soil response during the installation of XCC pile. Full-scale field tests were carried out to assess the soft soil response during the installation of the XCC pile, and to evaluate the performance of the XCC pile supported embankment under vertical loads. Static load tests indicated that the XCC pile appeared to provide considerably larger enhancement than the flexible or semirigid columns. More stresses were distributed to the XCC pile head, due to the arching effect caused by the differential settlement between the pile and its surrounding soil. The ratio of the stress concentration of the XCC pile foundation increased with the embankment height. Lateral displacements for the reinforced embankment were small, indicated that the XCC pile was capable of preventing lateral deformation and enhanced the stability of the embankment [1]. A static pile load test was conducted on composite foundation with XCC pile in layered soft clay. Vertical load test was also performed on conventional pile with same cross section area. Open arc spacing equal to 0.11 $\mathrm{m}$ and open arc angle equal to $90^{\circ}$ were taken in case of XCC pile. It was concluded that bearing capacity of XCC pile was $24.8 \%$ higher than of conventional pile with reduction of settlement. The load sharing of XCC pile was also greater than that of circular pile. The side friction was positive after depth of $2 \mathrm{~m}$ [2].

\section{METHODOLOGY}

\section{A. Experimental test set up}

The experiment setup in the present investigation comprised of the modeled pile, hydraulic jack, loading frame, vertical displacement measuring unit, proving ring and a test tank. The model pile load test was conducted according to IS:2911- (part 4) 1985 and vertical load capacity was evaluated. The hydraulic jack consisting of loading unit and pumping unit was used for application of load. A proving ring (5.0 kN capacity) was used for recording of loading. The schematic of test setup is as shown in Fig 1.

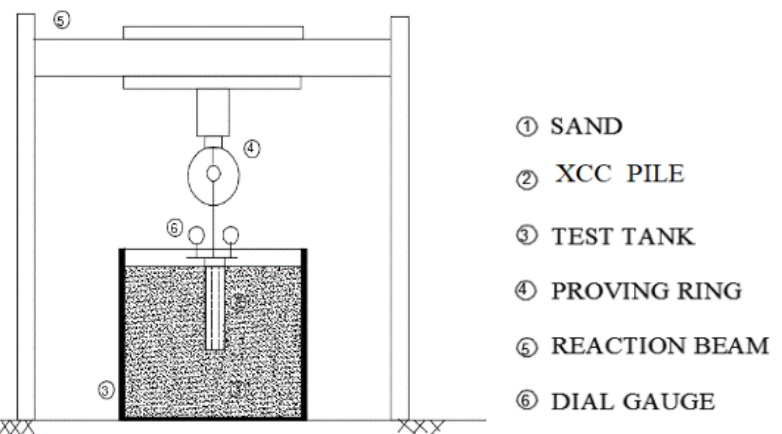

Fig. 1: The schematic diagram of the test setup for vertical loading used for experimental investigation 
Two dial gauges accurate to $0.01 \mathrm{~mm}$ were used for displacements measurement. A Square steel tank with inner dimensions $650 \mathrm{~mm}$ long, $650 \mathrm{~mm}$ wide and $650 \mathrm{~mm}$ high was used to conduct test. The inside walls of the tank were polished to reduce the friction with the sand as much as possible. The tank was designed to be large enough so that there would be no interference between the walls of the tank and the failure zone around the piles.

The model lateral pile load test was conducted according to IS:2911- (part 4) 1985 and lateral load capacity was evaluated. The lateral load to the piles was applied with help of a pulley and non-extensible wire system as shown in Fig. 2. A dial gauge of $0.01 \mathrm{~mm}$ sensitivity, horizontally fixed on side edge of tank was used to measure the lateral displacement of pile at the top. Standard weights were used for loading. The increments of about 20 percent of the estimated safe load was applied for each load increment and was kept constant for 30 minutes. The next increment was applied and test was continued till failure displacement of pile was recorded.

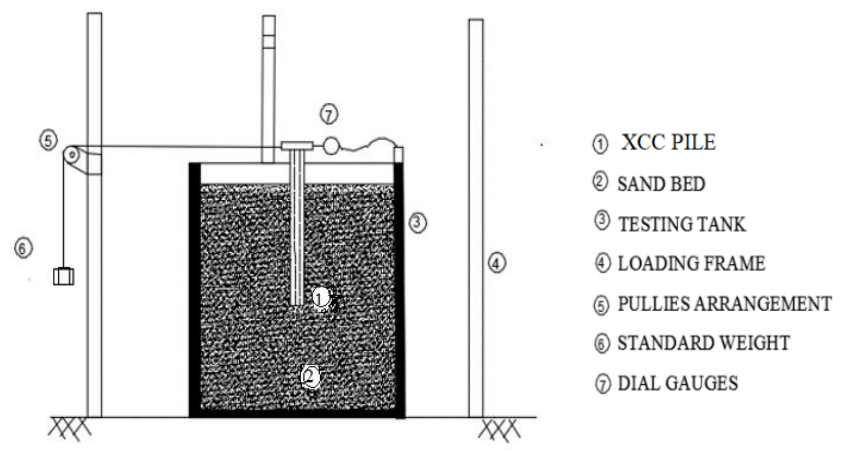

Fig. 2: The schematic diagram of the test setup for lateral loading used for experimental investigation

The static uplift load tests were conducted on piles in accordance of IS: 2911-(Part 4) 1985. The static uplift load was applied in number of increments by adding standard weights through a loading arrangement as shown in Fig. 3. Pile head movement was measured for each load increment. When the pile head movement was stopped then the next load increment was applied. The procedure was repeated till the failure displacement of pile was recorded or the sudden pull out of pile occurred.

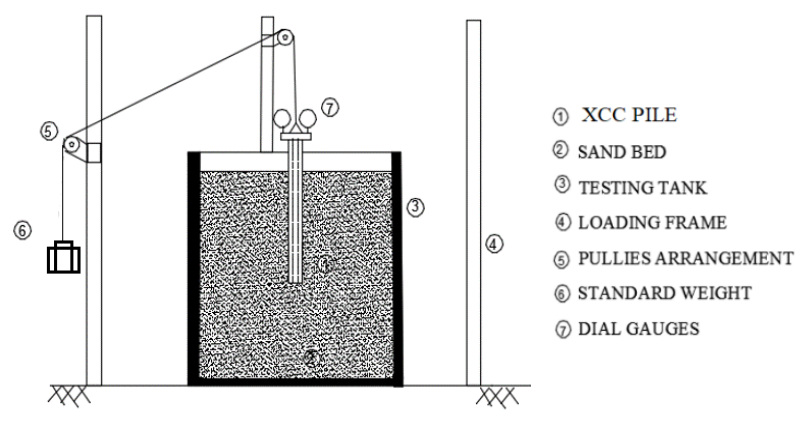

Fig. 3: The schematic diagram of the test setup for uplift loading used for experimental investigation

\section{B. Material}

Locally available cohesionless, dry and clean sand passing through $2 \mathrm{~mm}$ IS sieve was used for test. Relative density of sand was maintained at $45 \%$ for all the tests. Different engineering properties of sand were found out with the help of laboratory test as per IS codes. According to the IS soil classification system, the sand was graded as poorly graded sand (SP). Table I shows the properties of the sand used.

Table I: Properties of sand used

\begin{tabular}{|c|l|c|}
\hline Sr. no & Properties of sand & Values \\
\hline 1 & Specific gravity & 2.67 \\
\hline 2 & Relative density (\%) & 45 \\
\hline 3 & $\gamma_{\max }\left(\mathrm{kN} / \mathrm{m}^{3}\right)$ & 17.34 \\
\hline 4 & $\gamma_{\min }\left(\mathrm{kN} / \mathrm{m}^{3}\right)$ & 16.22 \\
\hline 5 & Angle of internal friction $(\phi)$ & 42 \\
\hline 6 & Cohesion $\left(\mathrm{kN} / \mathrm{m}^{2}\right)$ & 0 \\
\hline 7 & IS Classification & SP (Medium Sand) \\
\hline
\end{tabular}

\section{Model Pile Foundation}

Model pile were made up of Aluminum. The length and diameter of pile were $30 \mathrm{~cm}$ and $2 \mathrm{~cm}$, respectively. The Fig 4a and 4b shows the typical model XCC pile and schematic diagram of XCC pile.

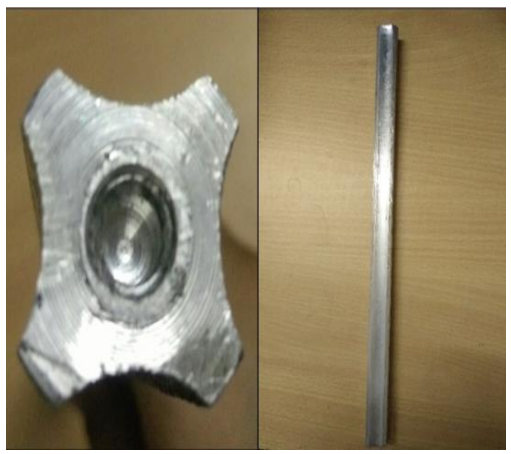

(a)

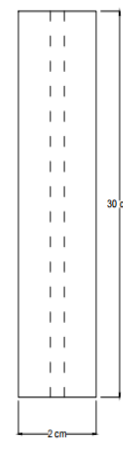

(b)

\section{Fig. 4: Model XCC Pile Used in Experimental investigations}

Tests were carried out on single XCC pile and circular pile as well as groups of pile. Piles were attached to pile cap with Nut-Bolt arrangement. A small groove was provided on center of pile cap for application of axial load. pile was attached to pile cap with Nut-Bolt arrangement. A small groove was provided on center of pile cap for application of axial load.

\section{Installation of Model pile in sand}

'Undisturbed method of pile installation' was used for installation of model pile in sand and no displacement of soil around the pile occurred with use of this method. The sand was filled up to the pile tip with calculated the height of fall to achieve the required relative density. Sand was filled again to full the tank. Pile was kept vertical during this process. The stress condition around the pile was assumed to stimulate with use of this procedure of pile installation. After each test the tank was emptied and process was repeated for conducting the next test.

\section{E. Test program}

Experimental tests were carried out on model XCC pile and conventional circular pile embedded in sand. The tests were conducted on model pile with varying and constant parameter as shown in Table II. Detailed experimental program of tests is given in Table II.

\section{Published By:}

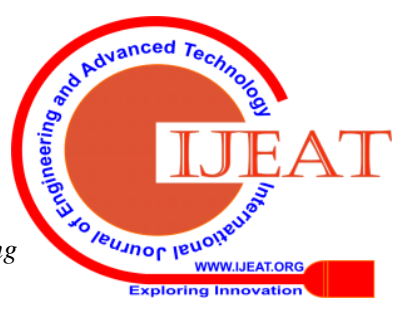


Table II: Details of experimental program (Constant and varying parameter)

\begin{tabular}{|c|c|c|c|}
\hline $\begin{array}{l}\text { Sr. } \\
\text { No }\end{array}$ & Parameters & $\begin{array}{c}\text { Varying } \\
\text { Parameters }\end{array}$ & $\begin{array}{c}\text { Constant } \\
\text { parameters }\end{array}$ \\
\hline 1 & $\begin{array}{l}\text { Distance } \\
\text { between Arc } \\
\text { of Pile 'b' } \\
(\mathrm{mm})\end{array}$ & 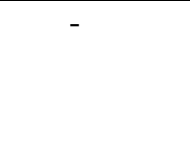 & $\begin{aligned} \text { i. } & 4.0 \\
\text { ii. } & 6.0 \\
\text { iii. } & 8.0 \\
\text { iv. } & 10\end{aligned}$ \\
\hline 2 & b/D Ratio & - & $\begin{array}{ll}\text { i. } & 0.2 \\
\text { ii. } & 0.3 \\
\text { iii. } & 0.4 \\
\text { iv. } & 0.5\end{array}$ \\
\hline 3 & $\begin{array}{l}\text { Type of } \\
\text { Loading }\end{array}$ & - & $\begin{array}{l}\text { i. Axial Loading } \\
\text { ii. Lateral Loading } \\
\text { iii. Uplift Loading }\end{array}$ \\
\hline 4 & $\begin{array}{l}\text { Number of } \\
\text { Piles }\end{array}$ & - & $\begin{array}{l}\text { i. Single pile } \\
\text { ii. Pile group with } \\
3,4,6 \text { and } 9 \text { piles }\end{array}$ \\
\hline 5 & $\begin{array}{l}\text { Diameter of } \\
\text { pile, D (mm) }\end{array}$ & 20 & - \\
\hline 6 & $\begin{array}{l}\text { Length of Pile, } \\
\text { L (mm) }\end{array}$ & 300 & - \\
\hline 7 & $\begin{array}{l}\text { Slenderness } \\
\text { ratio (L/D) }\end{array}$ & 15 & - \\
\hline 8 & $\begin{array}{l}\text { Spacing of } \\
\text { piles in the } \\
\text { group }\end{array}$ & $3 \mathrm{D}$ & - \\
\hline
\end{tabular}

\section{EXPERIMENTAL RESULTS AND DISCUSSION}

The pile load test was conducted on single circular pile for vertical, lateral and uplift load. The load vs settlement curves were plotted as shown in Fig 5a to give ultimate load capacity. Fig 5b shows lateral load vs. lateral displacement curve and Fig 5c shows uplift load vs pile head displacement curve for circular pile and values are as shown in Table III.

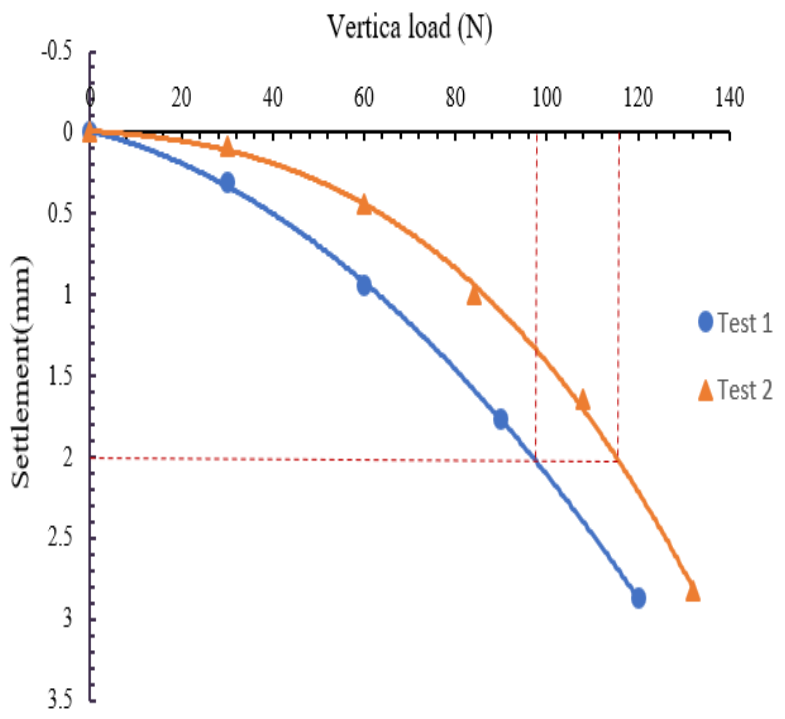

(a)

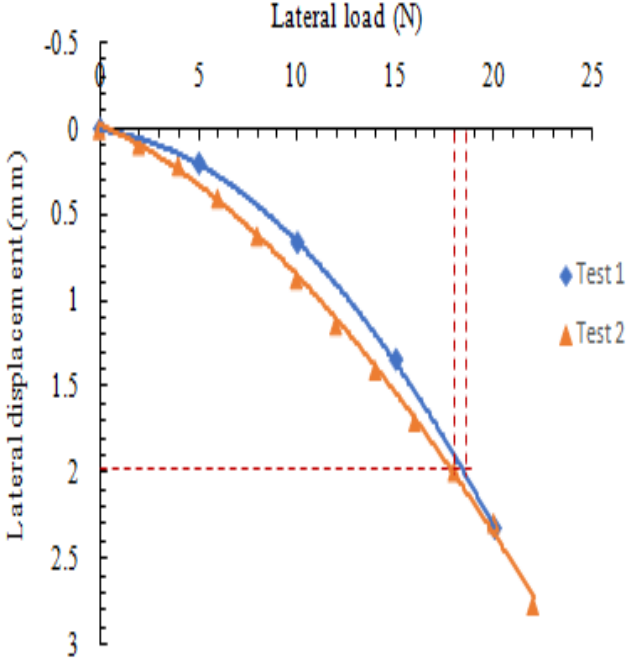

(b)

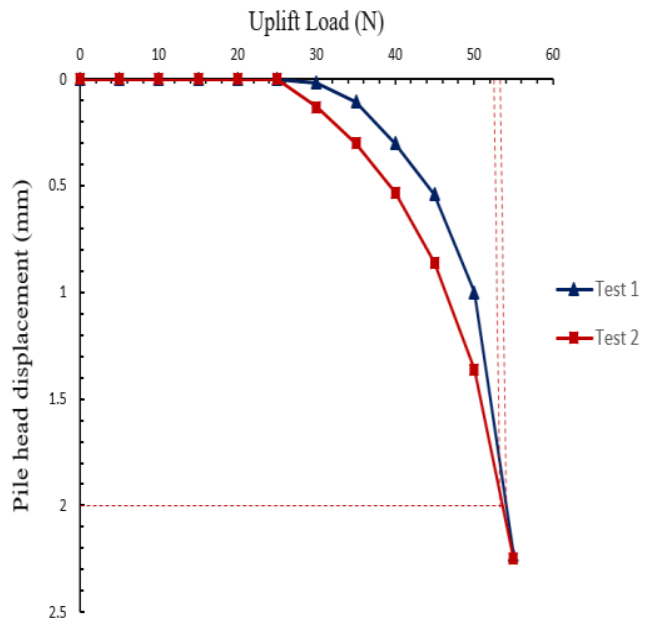

(c)

Fig 5: (a) Load vs settlement curve for vertical load test for circular pile, (b) Lateral load vs. displacement curve for lateral load test for circular pile and (c) Uplift load vs. pile head displacement curve for uplift load test for circular pile

Table III: Ultimate vertical load capacity, lateral load capacity and uplift load capacity of conventional pile

\begin{tabular}{|l|c|}
\hline $\begin{array}{l}\text { Type of } \\
\text { Loading }\end{array}$ & $\begin{array}{c}\text { Ultimate load } \\
\text { capacity (N) }\end{array}$ \\
\hline $\begin{array}{l}\text { Vertical } \\
\text { loading }\end{array}$ & 108 \\
\hline Lateral loading & 18 \\
\hline & \\
Uplift loading & 53 \\
\hline
\end{tabular}

Pile load tests were also conducted on XCC pile with b/D ratio equal to $0.2,0.3,0.4$, and 0.5 . Results obtained from vertical, lateral and uplift load are as shown in Fig 6 and values obtained are shown in Table IV. 


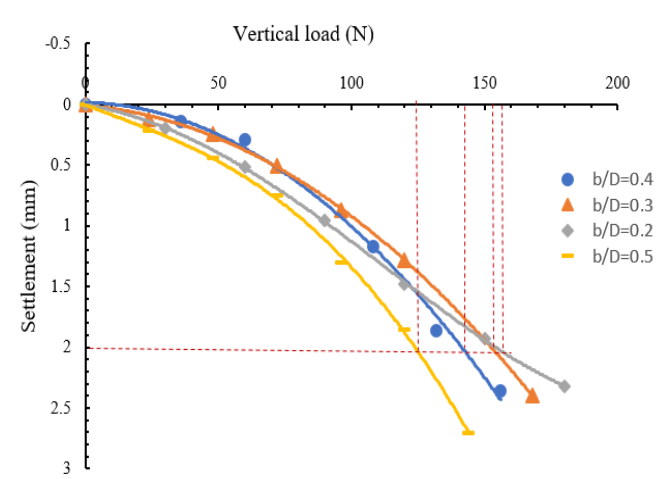

(a)

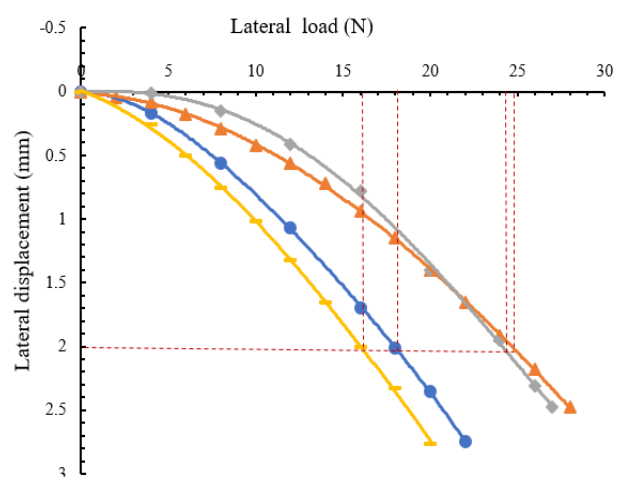

(b)

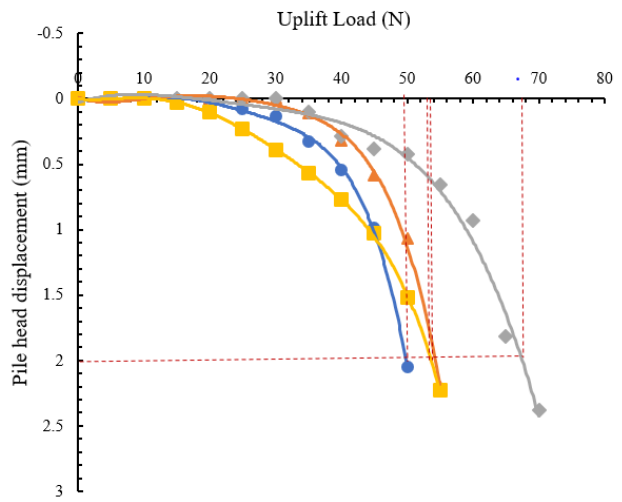

(c)

Fig 6: (a) Load vs settlement curves for vertical load test for XCC Pile, (b) Lateral load vs. displacement curves for lateral load test for XCC pile and (c) Uplift load vs. pile head displacement curves for uplift load test for XCC pile

Table IV: Ultimate vertical load capacity, lateral load capacity and uplift load capacity of XCC pile

\begin{tabular}{|c|c|c|c|}
\hline $\begin{array}{c}\text { Type of } \\
\text { pile }\end{array}$ & $\begin{array}{c}\text { Ultimate } \\
\text { load } \\
\text { capacity } \\
\text { (N) }\end{array}$ & $\begin{array}{c}\text { Ultimate } \\
\text { Lateral load } \\
\text { capacity (N) }\end{array}$ & $\begin{array}{c}\text { Pull-out load } \\
\text { capacity (N) }\end{array}$ \\
\hline $\begin{array}{c}\text { XCC } \\
\text { pile (b/D } \\
=0.2)\end{array}$ & 153 & & \\
\hline
\end{tabular}

\begin{tabular}{|c|c|c|c|}
$\begin{array}{c}\text { XCC } \\
\text { pile (b/D } \\
=0.3)\end{array}$ & 156 & 25 & \\
\hline $\begin{array}{c}\text { XCC } \\
\text { pile (b/D } \\
=0.4)\end{array}$ & 138 & 24 & 64 \\
\hline $\begin{array}{c}\text { XCC } \\
\text { pile (b/D } \\
=0.5)\end{array}$ & 124 & 16 & \\
\hline
\end{tabular}

Vertical, Lateral and uplift load tests were also carried out on XCC pile and conventional pile with number of piles equal to 3 (in triangular arrangement), 4 (in square arrangement), 6 (in( hexagonal arrangement and row arrangement) and 9 bpiles (in three row arrangement). Ultimate capacities of pile and percentage increment in ultimate capacities are represented in the form of bar charts as shown in Fig 7.

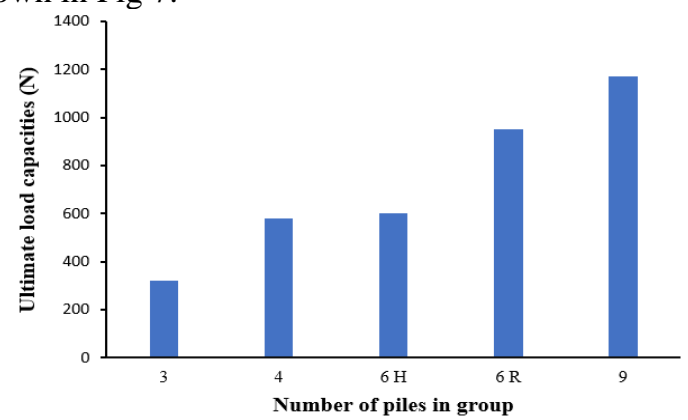

(a)

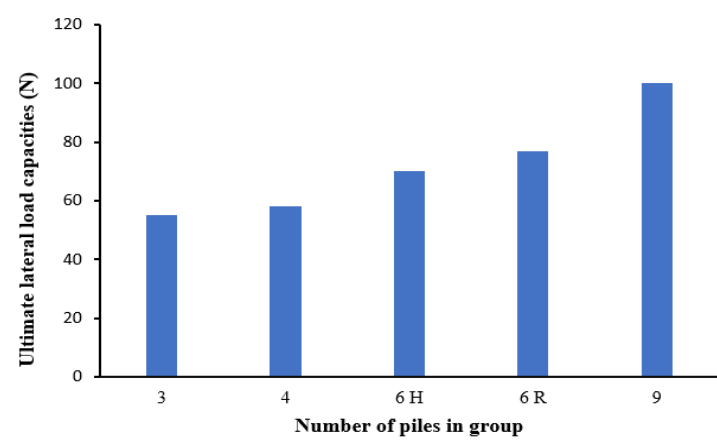

(b)

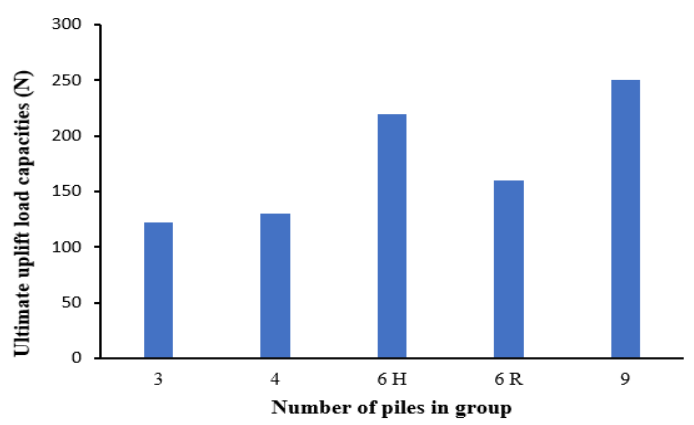

(c)

Fig 7: (a) Ultimate load capacities of XCC pile groups with numbers of piles in group, (b) Ultimate lateral load capacities of XCC pile groups with numbers of piles in group, and (c) Ultimate lateral load capacities of XCC pile groups with numbers of piles in group

Published By:

Blue Eyes Intelligence Engineering 4349 \& Sciences Publication 
Table V shows Ultimate load capacities of group of circular and XCC pile under different load conditions with \% increment in it for different pile groups. Fig 8 shows \% Increment or decrement in Ultimate load capacities of XCC pile group with number of piles in the group with respect to vertical, lateral and uplift loading. the group, (b) Ultimate Lateral load capacities of XCC pile group with number of piles in the group, and (c) Ultimate uplift load capacities of XCC pile group with number of piles in the group

Table V: Ultimate load capacities of group of circular and XCC pile under different load conditions

\begin{tabular}{|l|c|c|c|c|c|c|c|c|c|}
\hline \multicolumn{1}{|c|}{ Type of group } & \multicolumn{2}{|c|}{ Ultimate load capacity (N) } & \multicolumn{2}{c|}{ Lateral load capacity (N) } & \multicolumn{3}{c|}{ Uplift load capacity (N) } \\
\cline { 2 - 11 } & $\begin{array}{c}\text { Circular } \\
\text { pile }\end{array}$ & $\begin{array}{c}\text { XCC } \\
\text { pile }\end{array}$ & $\begin{array}{c}\text { \% } \\
\text { increase }\end{array}$ & $\begin{array}{c}\text { Circular } \\
\text { pile }\end{array}$ & $\begin{array}{c}\text { XCC } \\
\text { pile }\end{array}$ & $\begin{array}{c}\text { \% } \\
\text { increase }\end{array}$ & $\begin{array}{c}\text { Circular } \\
\text { pile }\end{array}$ & $\begin{array}{c}\text { XCC } \\
\text { pile }\end{array}$ & increase \\
\hline $\begin{array}{l}\mathrm{n}=3 \text { (Triangular } \\
\text { arrangement) }\end{array}$ & 340 & 320 & -20 & 48 & 55 & 14.6 & 130 & 122 & -6.2 \\
\hline $\begin{array}{l}\mathrm{n}=4 \text { (Square } \\
\text { arrangement) }\end{array}$ & 520 & 580 & 11.53 & 57 & 58 & 1.75 & 205 & 130 & -36 \\
\hline $\begin{array}{l}\mathrm{n}=6 \text { (Hexagonal } \\
\text { arrangement) }\end{array}$ & 660 & 600 & 6.15 & 80 & 77 & -3.75 & 180 & 220 & 22 \\
\hline $\begin{array}{l}\mathrm{n}=6 \text { (Two Row } \\
\text { arrangement) }\end{array}$ & 720 & 950 & 32 & 65 & 70 & 7.7 & 160 & 160 & 0 \\
\hline $\begin{array}{l}\mathrm{n}=9 \text { (Three Row } \\
\text { arrangement) }\end{array}$ & 650 & 1170 & 80 & 94 & 100 & 6.4 & 220 & 250 & 13.6 \\
\hline
\end{tabular}

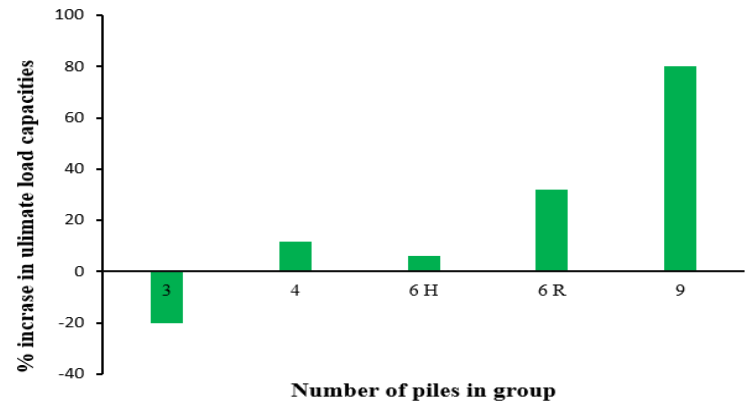

(a)

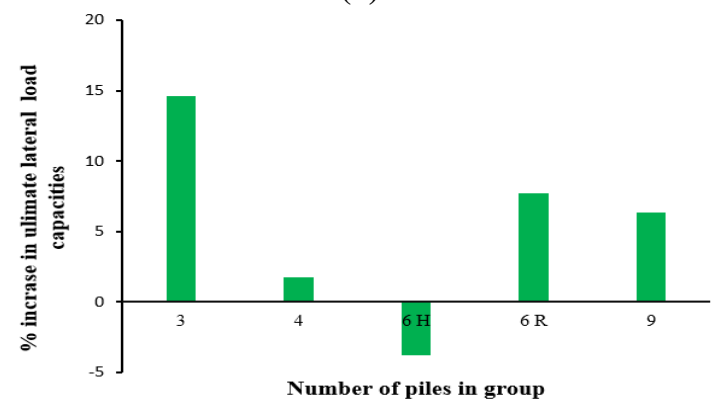

(b)

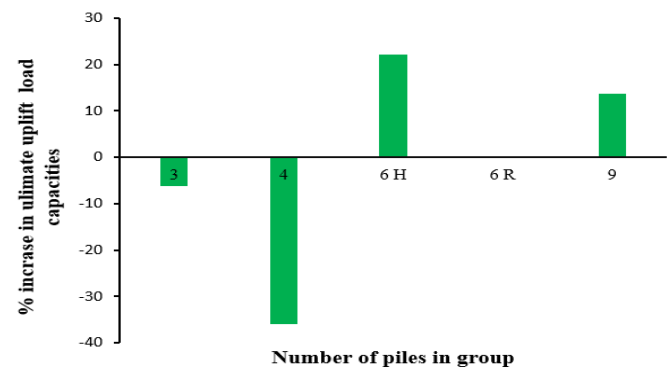

(c)

Fig 8: \% Increment or decrement in (a) Ultimate load capacities of XCC pile group with number of piles in

\section{CONCLUSIONS}

Following are the conclusions drawn on the basis of present study

1. The vertical load capacity of single XCC Pile is higher than that of conventional pile. (up to $45 \%$ )

2. The lateral load capacity of single XCC Pile is higher than that of Conventional pile. (up to $39 \%$ )

3. The uplift load capacity of single XCC pile is higher at arc distance to diameter ratio equal to 0.4 and less for other ratios. (29\%)

4. The ultimate load capacity and lateral load capacity of XCC pile with arc distance to diameter ratio equal to 0.3 are higher as compared to other ratios of arc distance to diameter.

5. The percentage increase in ultimate load capacity of group of four pile in square arrangement is higher as compared to conventional pile. (12\%)

6. The percentage increase in ultimate capacity of group of six piles in row arrangement is higher as compared to conventional pile group. (up to $32 \%$ )

7. The percentage increase in ultimate capacity of group of nine piles in row arrangement is higher as compared to conventional pile group. (up to $80 \%$ )

8. The percentage increase in ultimate lateral load capacity of group of three piles in triangular arrangement is higher as compared to conventional pile group. (up to $15 \%$ )

\section{REFERENCES}

1. Yaru Lv, Xuanming Ding and Hanlong liu, "In-situ Tests on cast-inplace Concrete X-section Pile for Bearing Capacity of Single-pile Composite Foundation”, Geotechnical Special Publication No. 220 (C) ASCE, 2011, pp.39-47. 
2. Xuanming Dinga, Lubao Luana, Hanlong Liua, Changjie Zhengb, Hang Zhoua, Hongyu Qinca, "Key Laboratory of New Technology for Construction of Cities in Mountain Area," College of Civil Engineering, Chongqing University, 2019, pp.1-12.

3. GangQiang Kong, YuMin Chen, HanLong Liu, and Robert Y. Liang, F., "Numerical Analysis of X-section Cast-in-place Concrete Pile Groups Under Vertical Load", Geotechnical Special Publication No. 220 ( ) ASCE, 2011, pp.162-168.

4. Yaru Lv, Xuanming Ding and Hong liu, "Field Test on Bearing Characteristics of X-Section pile composite foundation", Journal of Performance of Constructed Facilities, Research Gate, 2012, pp.180189.

5. Hang Zhou and Zhaohu Cao, "Measuring Effects of X-section pile installation in soft clay", Research Gate, 2015, pp.296-205.

6. Anju Kumari, Prof. S. W. Thakare and Dr. A.I. Dhatrak. "Analysis of barrette pile in sand", National Conference on Recent Advancement in Geotechnical Engineering, 2018, pp.27-30.

7. Dr. A. I. Dhatrak, Maithily Ghawde and Prof. S. W. Thakare, "Experimental study on Belled Wedge Pile for different loadings in cohesionless soil," Indian Geotechnical Conference, Indian Institute of Science Bengaluru, 2018, pp.1-7.

8. N. G. Tale, Dr. A. I. Dhatrak, Prof. S. W. Thakare."Numerical Analysis of Spin Fin Pile under Different Loading Conditions," International Journal of Technical Innovation in Modern Engineering \& Science (IJTIMES), Volume 5, Issue 05, e-ISSN: 2455-2585, 2018 , pp.659-664.

9. Prof. S. W. Thakare, P. P. Wankhade, Dr. A. I. Dhatrak. (2019). "Experimental Investigations on Performance of Spin Fin Pile under Different Loading Modes." International Journal of Technical Innovation in Modern Engineering \& Science (IJTIMES), Volume 5, Issue 05, e-ISSN: 2455-2585, 2018, pp.501-506.

10. "Indian Standard Code of Practice for Design and Construction of Pile Foundation”, IS code 2911 (Part- IV)-1985.

\section{AUTHOURS PROFILE}

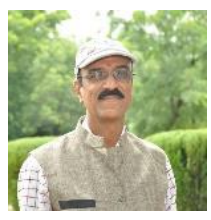

Dr. A. I. Dhatrak is working as Associate Professor in Civil Engineering Department, and Dean Academics at Government College of Engineering, Amravati, India. With thirty-one year of experience, he has completed his Ph.D. in 2014. He has more than 90 publication in national and international journal and conferences. He has guided more than 40 students in their Post-Graduation dissertation in geotechnical Engineering. Currently he is guiding six Ph.D. student and thirteen master students in geotechnical engineering.

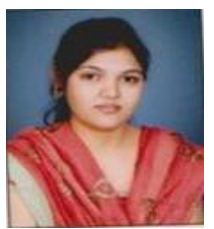

B. M. Kalbande has completed her Bachelor's degree in Civil Engineering from Rashtrasant Tukdoji Maharaj Nagpur University, India. She has worked as lecturer for two years at Shri Datta Meghe Polytechnic, Nagpur, India. Currently she is pursuing her Master Degree in Geotechnical Engineering at Government College of Engineering, Amaravati, India.

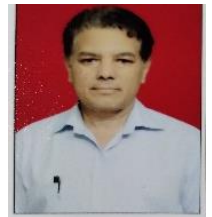

S. W. Thakare is working as Associate professor in Department of civil Engineering, Government college of Engineering, Jalgaon, India. Currently with thirtytwo years of experience, he pursuing his Ph.D. in "Evaluation of capacities of Barrette Pile Foundation in Sandy soil" at Government college of Engineering, Amravati, India. He has published 40 research paper in various national and international journals and conferences. He has guided about 40 students for their Post-Graduation dissertation in Geotechnical Engineering. 